\title{
Physicochemical Characterization of Crithmum maritimum L. and Daucus carota subsp. gummifer (Syme) Hook.fil. and Their Antimicrobial Activity against Apple Tree and Grapevine Phytopathogens
}

\author{
Eva Sánchez-Hernández ${ }^{1}$, Laura Buzón-Durán ${ }^{1}$, Celia Andrés-Juan ${ }^{2}$, Belén Lorenzo-Vidal ${ }^{3}$, Jesús Martín-Gil ${ }^{1}$ (D) \\ and Pablo Martín-Ramos $4, * \mathbb{D}$ \\ 1 Agriculture and Forestry Engineering Department, ETSIIAA, Universidad de Valladolid, \\ Avenida de Madrid 44, 34004 Palencia, Spain; eva.sanchez.hernandez@uva.es (E.S.-H.); \\ laura.buzon@uva.es (L.B.-D.); mgil@iaf.uva.es (J.M.-G.) \\ 2 Departamento de Química Orgánica, Facultad de Ciencias, Universidad de Valladolid, Calle Paseo de Belén 7, \\ 47011 Valladolid, Spain; celia.andres.juan@uva.es \\ 3 Servicio de Microbiología, Hospital Universitario Rio Hortega, Calle Dulzaina 2, 47012 Valladolid, Spain; \\ blorenzov@saludcastillayleon.es \\ 4 Instituto Universitario de Investigación en Ciencias Ambientales de Aragón (IUCA), EPS, \\ Universidad de Zaragoza, Carretera de Cuarte s/n, 22071 Huesca, Spain \\ check for \\ updates
}

Citation: Sánchez-Hernández, E.; Buzón-Durán, L.; Andrés-Juan, C.; Lorenzo-Vidal, B.; Martín-Gil, J.; Martín-Ramos, P. Physicochemical Characterization of Crithmum maritimum L. and Daucus carota subsp. gummifer (Syme) Hook.fil. and Their Antimicrobial Activity against Apple Tree and Grapevine Phytopathogens. Agronomy 2021, 11, 886. https:// doi.org/10.3390/agronomy11050886

Academic Editors: Célia Cabral and Elisa Julião Campos

Received: 29 March 2021

Accepted: 28 April 2021

Published: 30 April 2021

Publisher's Note: MDPI stays neutral with regard to jurisdictional claims in published maps and institutional affiliations.

Copyright: () 2021 by the authors. Licensee MDPI, Basel, Switzerland. This article is an open access article distributed under the terms and conditions of the Creative Commons Attribution (CC BY) license (https:// creativecommons.org/licenses/by/ $4.0 /)$.

\begin{abstract}
Crithmum maritimum and Daucus carota subsp. gummifer are two species of the Apiaceae family that share multiple characteristics: both are halophitic, live on cliffs in the same geographic habitats, and are edible. While C. maritimum is rich in essential oils and flavonoids, D. carota is rich in terpenes and a gum producer. In the work presented herein, the biomass of these two wild plants and the bioactive compounds present in their extracts have been studied by elemental and thermal analysis, infrared spectroscopy, and gas chromatography-mass spectroscopy. To explore their bioactivities, both their hydroalcoholic extracts and their major constituents (apiole in C. maritimum and geranyl acetate in $D$. carota), either alone or in combination with chitosan oligomers, were assayed in vitro against bacterial and fungal pathogens that affect apple trees (Malus domestica) and grapevine (Vitis vinifera). Remarkable inhibition was observed against Erwinia amylovora, the causal agent of fire blight in apple; Xylophilus ampelinus [syn. Erwinia vitivora], the causal agent of bacterial blight of grapevine; and Diplodia seriata, a virulent pathogen of grapevines that also causes canker, leaf spot and fruit rot of apple. In view of their effectiveness against these three phytopathogens, a potential application of these two medicinal plants in organic farming may be envisaged.
\end{abstract}

Keywords: antibacterial; antifungal; apiole; chitosan; Diplodia seriata; Erwinia amylovora; geranyl acetate; Viticulture; Xylophilus ampelinus

\section{Introduction}

Crithmum maritimum L., the sole species of Crithmum genus, is a perennial wild plant that is found on cliffs in southern and western coasts of the British Isles, on western and Mediterranean coasts of Europe, in North Africa and the Canary Islands. It is known as samphire, rock samphire, sea fennel, and, in Asturias (Spain), as cenoyo de mar. It belongs to the Apiaceae family and is an oleaginous halophyte. It has fleshy, divided aromatic leaves, which have a hot and spicy taste (Figure 1). A detailed morphological description, together with a discussion of its eco-physiological responses to salt stress, may be found in the review paper by Atia, et al. [1]. 

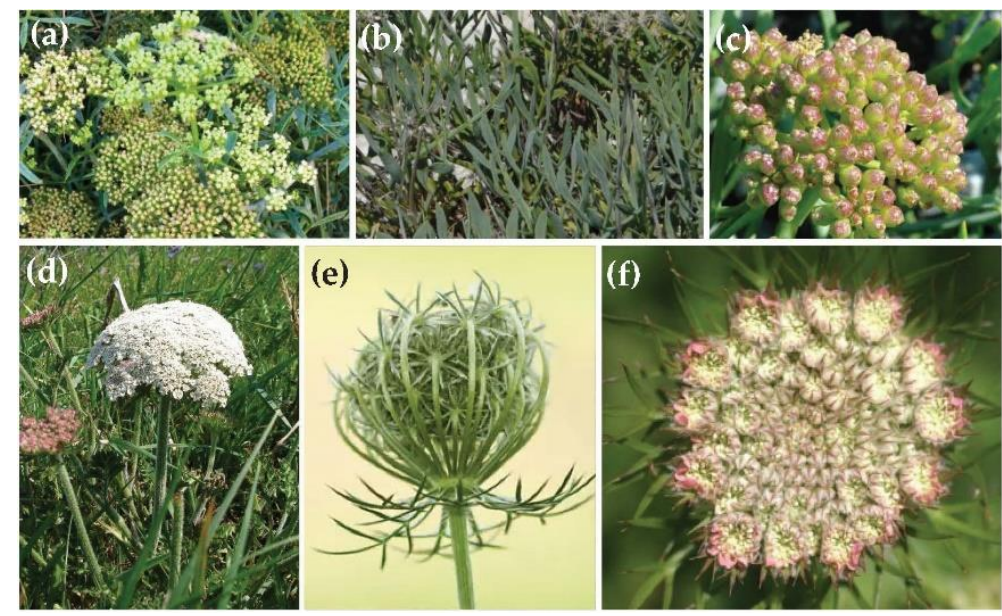

(e)

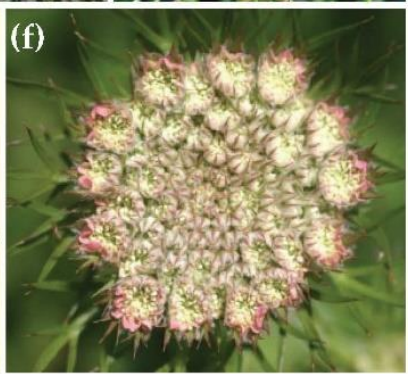

Figure 1. Morphology of Crithmum maritimum L. (a-c) and Daucus carota subsp. gummifer Hook.fil. (d-f).

Daucus carota subsp. gummifer (Syme) Hook.fil. is also a member of the Apiaceae, and is a herb of maritime cliffs, dunes, and grasslands. It is mostly found on the northern coast of Spain, although it may also be found on southern and western coasts of Britain. The common names of this D. carota subspecies include sea carrot, wild carrot, bird's nest, bishop's lace, and Queen Anne's lace. In Spanish language, it is named zanahoria de acantilado (tr. cliff carrot). It is hairy, with a stiff, solid stem (Figure 1). The leaves are tripinnate, finely divided, lacy, triangular in shape. Its flowers-small and white, clustered in flat, dense umbels-are sometimes battered and fried. The root is edible while young, but it quickly becomes too woody to consume. The leaves are also edible in little quantities. It contains small amounts of toxicant cyanogenic glycosides [2].

These two medicinal plants have been reported to produce interesting secondary metabolites [3]. Spectrometric analyses of the contents of flavonoids, tannins, and total polyphenols in the aerial parts of rock samphire collected on the Adriatic coast of Croatia in different growth stages were reported by Males, et al. [4], with the highest contents of above components in the samples collected before flowering. Phenolic acids, such as caffeic, chlorogenic, ferulic, p-hydroxybenzoic, p-coumaric vanillic, protocatechuic, and syringic acids were identified by Bartnik, et al. [5]. According to Pavela, et al. [6], the essential oils (EO) of C. maritimum show notable variability in chemical composition, being dominated by dillapiole and $\gamma$-terpinene (French EO), limonene and $\gamma$-terpinene (central Italy EO), and thymol methyl ether and $\gamma$-terpinene (Sicilian EO).

In turn, $D$. carota subs. gummifer has been reported to contain high contents of monoterpenes $(83.9 \%)$, the major compounds being geranyl acetate [7] and pinenes. The daucane sesquiterpene, carotol, has also been found in relatively high amounts (11\%) [8].

With regard to the potential applications of these bioactive compounds, the antimicrobial activity of the EO of C. maritimum has been assayed against common food-borne bacteria, finding significant inhibition against Escherichia coli, Candida albicans, Listeria innucia, Pseudomonas aeruginosa, Bacillus subtilis, Staphylococcus epidermidis, and Staphylococcus aureus $[9,10]$. Its antimicrobial activity against a panel of microorganisms, including clinical isolates and food-borne pathogens, has also been studied [11]. The EO obtained from D. carota (albeit not for subsp. gummifer) has been assayed against S. aureus, E. coli, P. aeruginosa, Enterobacter aerogenes, B. subtilis, Campylobacter jejuni, Microsporum canis, and C. albicans by Rossi, et al. [12], Ozcelik, et al. [13], and Pavoni, et al. [14]. Only Valente, et al. [8] and Nawel, et al. [15] explored the EO from D. carota subs. gummifer as a natural source of antifungals against clinical strains of bacteria, yeast, and filamentous fungi.

Nonetheless, to the best of the authors' knowledge, the efficacy of these wild plants extracts has barely been explored against pathogens affecting crop species: $C$. maritimum EO has only been tested against Erwinia carotovora (which causes beet vascular necrosis, blackleg of potato and other vegetables, and slime flux on various tree species) by 
Ruberto, et al. [16], and against Mycogone perniciosa (which causes severe crop losses in common mushroom cultivation) by Glamoclija, et al. [17]. In this work, their application to the control of apple tree (Malus domestica Borkh.) and grapevine (Vitis vinifera L.) pathogens, in particular against two bacteria, namely Erwinia amylovora (Burrill) and Xylophilus ampelinus (Panagopoulos, 1969) Willems et al., 1987 [syn. Erwinia vitivora], and a fungus, viz. Diplodia seriata De Not., is evaluated.

Erwinia amylovora is the causal agent of fire blight, a major global threat to commercial apple and pear production [18]. It is cataloged as a quarantine organism in the European Union, and it has been included in the top 10 plant pathogenic bacteria [19]. A panorama of this pathogen's biology, epidemiology, and control may be found in the recent review by Zhao, et al. [20]. X. ampelinus (syn. Xanthomonas ampelina and Erwinia vitivora [21]), the causal agent of bacterial necrosis of grapevines (known as "maladie d'Oléron" in France and "mal nero" in Italy), severely affects grape crops, resulting in harvest losses as high as 70\% of typical yield [22]. The European and Mediterranean Plant Protection Organization (EPPO) categorizes X. ampelinus as a quarantine A2 organism, and it is also a quarantine pest for the North American Plant Protection Organization (NAPPO) and the Interafrican Phytosanitary Council (IAPSC). Regarding D. seriata, it is a member of the Botryosphaeriaceae family, which are known to be pathogens, endophytes, and saprophytes on a wide range of woody hosts. $D$. seriata is a primary and virulent pathogen of grapevines [23,24], but it also causes frog-eye leaf spot, black rot and canker of apples [25-27].

Taking into consideration that EU regulation (Article 14 in Directive 2009/128/EC, Council Regulation (EC) 834/2007, Commission Regulation (EC) 889/2008, Regulation (EU) $2019 / 1009$, etc.) promotes the use of formulations based on natural products for Integrated Pest Management (IPM), valorization of these two halophytes from the Asturian coast (Spain) as antimicrobial agents for crop protection is proposed. To explore this possibility, a physicochemical characterization of $C$. maritimum and D. carota subsp. gummifer is first presented, followed by in vitro studies of the efficacy of their hydromethanolic extracts against the above-referred phytopathogens.

\section{Material and Methods}

\subsection{Plant Material and Chemicals}

C. maritimum and D. carota subsp. gummifer samples were collected in the cliffs near

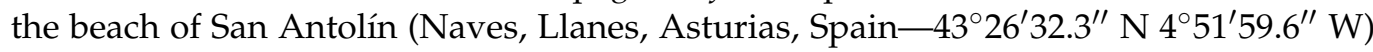
in early August, in full flowering. Plant parts from different specimens $(n=10$ for each species) were thoroughly mixed to obtain separate composite samples for roots, leaves, stems, and flowers.

Chitosan (CAS 9012-76-4; high MW: 310,000-375,000 Da) was supplied by Hangzhou Simit Chem. \& Tech. Co. (Hangzhou, China). Neutrase ${ }^{\mathrm{TM}} 0.8 \mathrm{~L}$ enzyme was supplied by Novozymes A/S (Bagsværd, Denmark). Chitosan oligomers (COS) were prepared according to the procedure previously reported in [28].

Apiole (1-allyl-2,5-dimethoxy-3,4-methylenedioxybenzene, CAS 523-80-8) was purchased from Cymit Química SL (Barcelona, Spain). Geranyl acetate (trans-3,7-dimethyl-2,6octadien-1-yl acetate, CAS 105-87-3), methanol (UHPLC, suitable for mass spectrometry, CAS 67-56-1), TSA (tryptic soy agar, CAS 91079-40-2) and TSB (tryptic soy broth, CAS 8013-01-2) were acquired from Sigma-Aldrich Química (Madrid, Spain). PDA (potato dextrose agar) was supplied by Becton Dickinson (Bergen County, NJ, USA).

\subsection{Bacterial and Fungal Isolates}

The two bacterial isolates, Erwinia amylovora (Burrill) and Xylophilus ampelinus (Panagopoulos, 1969) Willems et al., 1987 were supplied by the Spanish Type Culture Collection (CECT), with NCPPB 595 and CCUG 21976 strain designations, respectively. The fungal isolate under study, D. seriata (code ITACYL_F098, isolate Y-084-01-01a) was isolated from 'Tempranillo' diseased grapevine plants from protected designation of origin (PDO) Toro (Spain) and supplied as lyophilized vials (later reconstituted and refreshed as 
PDA subcultures) by the Agricultural Technological Institute of Castilla and Leon (ITACYL, Valladolid, Spain) [29].

\subsection{Preparation of Plant Extracts}

C. maritimum and D. carota subsp. gummifer flowering aerial parts were mixed (1:20, $w / v)$ with a methanol/water solution $(1: 1 \mathrm{v} / \mathrm{v})$ and heated in a water bath at $50{ }^{\circ} \mathrm{C}$ for $30 \mathrm{~min}$, followed by sonication for $5 \mathrm{~min}$ in pulse mode with a $1 \mathrm{~min}$ stop for each $2.5 \mathrm{~min}$, using a probe-type ultrasonicator model UIP1000hdT (Hielscher Ultrasonics, Teltow, Germany). The solution was then centrifuged at $9000 \mathrm{rpm}$ for $15 \mathrm{~min}$ and the supernatant was filtered through Whatman No. 1 paper. Aliquots were lyophilized for CHNS analyses.

\subsection{Plant Biomass and Extracts Physicochemical Characterization}

Elemental analyses were carried out with a LECO (St. Joseph, MI, USA) CHNS-932 apparatus (model No. 601-800-500).

Thermal gravimetric (TGA) and differential scanning calorimetry (DSC) analyses were carried out by means of a simultaneous TG-DSC2 (Mettler Toledo; Columbus, OH, USA), in $\mathrm{N}_{2}: \mathrm{O}_{2}(4: 1)$, with a flow heating rate of $20^{\circ} \mathrm{C} \cdot \mathrm{min}^{-1}$.

The infrared vibrational spectra were registered using a Thermo Scientific (Waltham, MA, USA) Nicolet iS50 Fourier-transform infrared spectrometer, equipped with an in-built diamond attenuated total reflection (ATR) system. The spectra were collected with a $1 \mathrm{~cm}^{-1}$ spectral resolution over the $400-4000 \mathrm{~cm}^{-1}$ range, taking the interferograms that resulted from co-adding 64 scans.

The colorimetric quantification of total polyphenol content (TPC) and total flavonoid content (TFC) was conducted according to the procedures described in [30], using an Agilent (Santa Clara, CA, USA) UV-Vis Cary 100 spectrometer. Contents were expressed in GAE (gallic acid equivalents) and CE (catechin equivalents), respectively. Total carotenoids in $D$. carota subsp. gummifer were also determined spectrophotometrically, following the methodology described by Garcia Camacho, et al. [31].

The hydroalcoholic plant extracts were studied by gas chromatography-mass spectrometry (GC-MS) at the Research Support Services (STI) at Universidad de Alicante (Alicante, Spain), using a gas chromatograph model 7890A coupled to a quadrupole mass spectrometer model 5975C (both from Agilent Technologies). The chromatographic conditions were: injection volume $=1 \mu \mathrm{L}$; injector temperature $=280^{\circ} \mathrm{C}$, in splitless mode; initial oven temperature $=60^{\circ} \mathrm{C}, 2 \mathrm{~min}$, followed by ramp of $10^{\circ} \mathrm{C} / \mathrm{min}$ up to a final temperature of $300{ }^{\circ} \mathrm{C}, 15 \mathrm{~min}$. The chromatographic column used for the separation of the compounds was an Agilent Technologies HP-5MS UI of $30 \mathrm{~m}$ length, $0.250 \mathrm{~mm}$ diameter, and $0.25 \mu \mathrm{m}$ film. The mass spectrometer conditions were: temperature of the electron impact source of the mass spectrometer $=230^{\circ} \mathrm{C}$ and of the quadrupole $=150{ }^{\circ} \mathrm{C}$; ionization energy $=70 \mathrm{eV}$. NIST11 library was used for compound identification.

\subsection{In Vitro Antimicrobial Activity Assessment}

The antibacterial activity was assessed according to CLSI standard M07-11 [32], using the agar dilution method to determine the minimum inhibitory concentration (MIC). In short, an isolated colony of E. amylovora in TSB liquid medium was incubated at $30^{\circ} \mathrm{C}$ for $18 \mathrm{~h}$. Serial dilutions were then conducted, starting from a $10^{8} \mathrm{CFU} \cdot \mathrm{mL}^{-1}$ concentration, to obtain a final inoculum of $\sim 10^{4} \mathrm{CFU} \cdot \mathrm{mL}^{-1}$. Bacterial suspensions were then delivered to the surface of PDA plates, to which the bioactive products had previously been added at concentrations ranging from 62.5 to $1500 \mu \mathrm{g} \cdot \mathrm{mL}^{-1}$. Plates were incubated at $30^{\circ} \mathrm{C}$ for $24 \mathrm{~h}$. In the case of $X$. ampelinus, the same procedure was followed, albeit at $26^{\circ} \mathrm{C}$. Readings were taken after $24 \mathrm{~h}$. MICs were determined visually in the agar dilutions as the lowest concentrations of the bioactive products at which no bacterial growth was visible. All experiments were run in triplicate, with three 3 plates per treatment/concentration.

The antifungal activity of the different treatments was determined using the agar dilution method according to EUCAST standard antifungal susceptibility testing proce- 
dures [33], by incorporating aliquots of stock solutions onto the PDA medium to obtain concentrations in the $62.5-1500 \mu \mathrm{g} \cdot \mathrm{mL}^{-1}$ range. Mycelial plugs $(\varnothing=5 \mathrm{~mm})$, from the margin of 1-week-old PDA cultures of $D$. seriata, were transferred to plates incorporating the above-mentioned concentrations for each treatment (3 plates per treatment/concentration, with 2 replicates). Plates were incubated at $25^{\circ} \mathrm{C}$ in the dark for a week. PDA medium without any amendment was used as the control. Mycelial growth inhibition was estimated according to the formula: $\left(\left(d_{c}-d_{t}\right) / d_{c}\right) \times 100$, where $d_{c}$ and $d_{t}$ represent the average diameters of the fungal colony of the control and of the treated fungal colony, respectively. Effective concentrations $\left(\mathrm{EC}_{50}\right.$ and $\mathrm{EC}_{90}$ ) were estimated using PROBIT analysis in IBM SPSS Statistics v.25 (IBM; Armonk, NY, USA) software.

The level of interaction, i.e., synergy factors, were determined according to Wadley's method [34].

\subsection{Statistical Analysis}

The results of the inhibition of mycelial growth of $D$. seriata as affected by the different concentrations of the treatments were statistically analyzed using one-way analysis of variance (ANOVA), followed by post hoc comparison of means through Tukey's test at $p<0.05$. IBM SPSS Statistics v.25 software was used.

\section{Results and Discussion}

\subsection{Plant Biomass Characterization}

\subsubsection{Elemental Analysis of Plant Fractions}

The $\mathrm{C}, \mathrm{H}, \mathrm{N}$, and $\mathrm{S}$ percentages of $\mathrm{C}$. maritimum components were in the $36.6-40.0 \%$, $6.2-6.3 \%, 0.7-1.6 \%$, and $0.05-0.1 \%$ range, respectively, and those of D. carota subsp. gummifer in the $39.7-42.8 \%, 6.3-6.4 \%, 0.6-2.5 \%$, and $0.0-0.3 \%$ range, respectively (Table S1). The distribution of $\mathrm{N}$ content showed maximum values in the flowering aerial parts, resulting in $\mathrm{C} / \mathrm{N}$ ratio values noticeably lower than those found for stems and roots. Regarding the elemental analysis of the gels that resulted from the concentration by vacuum evaporation of the hydroalcoholic extracts of the flowering aerial parts of C. maritimum and D. carota subsp. gummifer, presented in Table S2, slightly higher $\mathrm{C} / \mathrm{N}$ ratios than those reported in Table S1 were observed.

\subsubsection{Thermal Characterization of Flowering Aerial Parts}

The DSC curve of the flowering aerial parts of C. maritimum (Figure S1) showed exothermic peaks at 290,330 , and $416^{\circ} \mathrm{C}$, in good correspondence with the exothermal effects associated with xylan and lignin [35]. From the TG curve, the ash content was $2.8 \%$. In the case of the umbel of D. carota subsp. gummifer (Figure S2), exothermal effects occurred at 323,402 , and $444{ }^{\circ} \mathrm{C}$, and the ash content was $2 \%$.

\subsubsection{Vibrational Characterization}

The FTIR spectra of the various fractions of $C$. maritimum (Table S3) showed the specific bands characteristic of oleaginous plants. In particular, the lipid acyl chains absorb at 2916 and $2848 \mathrm{~cm}^{-1}$, and at 1516 and $1320 \mathrm{~cm}^{-1}$, while at $1732 \mathrm{~cm}^{-1}$ the ester carbonyl IR response could be observed. The intensity of these bands was in agreement with the high concentrations of oils that this halophyte can store [36].

The spectra from D. carota subsp. gummifer (Table S3) featured three specific bands of carotenes at $\sim 1514, \sim 1147$, and $\sim 1009 \mathrm{~cm}^{-1}$. The intensity of the bands at 2360 and $2158 \mathrm{~cm}^{-1}$ (attributed to CN stretching) pointed to the presence of appreciable amounts of cyanogen glycosides and anthocyanin. Moreover, the intensity of the amide bands also suggested a significant amount of protein. A notable amount of pectin esters may be inferred from the presence of bands at 2918,1598 , and $\sim 808 \mathrm{~cm}^{-1}$, justifying the ability of this plant to produce gum. With regard to the spectrum from the concentrated gel obtained by evaporation of the hydromethanolic extract of $D$. carota subsp. gummifer (Figure S3), the peaks at 2916, 2849, 1732, 1369, 1237, 1144, 1095, and $1015 \mathrm{~cm}^{-1}$ were found to be in good 
correlation (shifts below $20 \mathrm{~cm}^{-1}$ ) with those of geranyl acetate $(2926,2858,1742,1377$, $1233,1163,1108$, and $\left.1024 \mathrm{~cm}^{-1}\right)$.

\subsubsection{On the Usefulness of the Above Physicochemical Techniques}

Valuable information may be retrieved from the elemental analysis data: $\mathrm{C} / \mathrm{N}$ ratios can shed light on the relative presence of carbohydrates and lipids vs. amines, amides, nitriles, and nitro compounds. Hence, the aerial parts, in which the lowest $\mathrm{C} / \mathrm{N}$ ratios were registered, are to be used if one would like to obtain a high content of bioactive heterocyclic compounds in the hydroalcoholic extracts.

Infrared spectral fingerprinting is useful to identify and/or fingerprint pectins, proteins, aromatic phenolics, cellulose, hemicellulose, etc. without-in most cases-the need for any physical separation [37]. The Apiaceae dicotyledonous herbs C. maritimum and D. carota are spectroscopically very different from the Gramineae due their higher degree of esterification, which can be crudely assessed by the ratio of the areas of the ester band (at around $1730 \mathrm{~cm}^{-1}$ ) to the polysaccharides band (at 1170-970 $\mathrm{cm}^{-1}$ ). Nevertheless, the spectra of C. maritimum exhibited five specific bands of cellulose $\left(1472 \mathrm{~cm}^{-1}, 1320 \mathrm{~cm}^{-1}\right.$, $1104 \mathrm{~cm}^{-1}, 1074 \mathrm{~cm}^{-1}, 1034 \mathrm{~cm}^{-1}$ ), and presence of xylan and lignin could also be inferred from the TG-DTG data for C. maritimum. This would support the hypothesis of Abideen, et al. [38], who put forward that the lignocellulosic biomass of this plant could be a potential source of biomass for bioethanol production.

On the other hand, given that the fatty acid methyl ester composition of the oils from C. maritimun and D. carota is comparable to those of other oil crops used for biodiesel production [39], and taking into consideration that their ash contents are not high, their valorization for this application, proposed by Sotiroudis, et al. [36], certainly deserves further attention.

Notwithstanding the above considerations on the utility of thermal and vibrational techniques for plant characterization and applications, they suffer from limitations to identify specific phytochemicals, making it necessary to make use of other more elucidative techniques, such as GC-MS (see below).

\subsection{Extracts Characterization}

\subsubsection{Phenolic Contents}

Extracts from C. maritimum from the Cantabrian Sea coast showed total phenolic contents (4.6-8.3 mg GAE. $\left.{ }^{-1} \mathrm{dw}\right)$ and total flavonoid contents $\left(3.0-5.6 \mathrm{mg} \mathrm{CE} \cdot \mathrm{g}^{-1} \mathrm{dw}\right)$ similar for those reported for Mediterranean origins, such as Tunisia [30,40] (4.1-7.9 mg GAE $\cdot \mathrm{g}^{-1} \mathrm{dw}$ and 2.9-6.1 $\mathrm{mg} \mathrm{CE} \cdot \mathrm{g}^{-1} \mathrm{dw}$ ) or the Adriatic coast in Croatia [4] (4.7-9.5 mg GAE. $\mathrm{g}^{-1} \mathrm{dw}$ and $\left.>3.7 \mathrm{mg} \mathrm{CE} \cdot \mathrm{g}^{-1} \mathrm{dw}\right)$.

For D. carota subsp. gummifer, the total phenolic content $\left(5.0 \mathrm{mg} \mathrm{GAE} \cdot \mathrm{g}^{-1}\right)$ was lower than those found by Ksouri, et al. [41] for D. carota L. spp. carota extracts (between 7.1 and $\left.13.8 \mathrm{mg} \mathrm{GAE} \cdot \mathrm{g}^{-1}\right)$. With regard to the amount of carotenoid components in the umbel extract, by our terpene analyses, it was $81 \mathrm{mg} \beta$-car $/ 100 \mathrm{~g} \mathrm{dw}$, slightly lower than that reported for $D$. carota leaves ( $83.5 \mathrm{mg} \beta$-car $/ 100 \mathrm{~g} \mathrm{dw}$ ) [42].

\subsubsection{Active Components by GC-MS Analysis}

GC-MS of C. maritimum hydromethanolic extracts (Table 1, Figure S4) allowed the identification of 1-allyl-2,5-dimethoxy-3,4-methylenedioxybenzene (apiole) $[\mathrm{m} / \mathrm{z}=77,106$, $121,149,177,207,222]$, methylthymol $[\mathrm{m} / \mathrm{z}=91,119,149,164]$, and 1,2-dimethyl-3phenylcyclopropene $[m / z=129]$ as major components. Apiole and methylthymol are in correspondence with dill-apiole (an isomer of apiole) and thymol methyl ether, two of the major components of $C$. maritimum essential oil from Kélibia and Monestir reported by Jallali, et al. [30]. Dill-apiole was also referred by Ngom, et al. [43], Houta, et al. [9], and Ben Mustapha, et al. [44]; and thymol methyl eter by Alves-Silva, et al. [45] and Nabet, et al. [10]. The main difference between the composition of our extracts and those reported by some authors $[9,10,46]$ is the absence of $\gamma$-terpinene and sabinene in the extracts presented herein. The presence of the polyacetylene falcarinol $[\mathrm{m} / \mathrm{z}=41,55,77,91,115,129,145$, 
159,173 ] was in correspondence with that of falcarindiol reported by Meot-Duros, et al. [47] and Ngom, et al. [43]. 1,2-dimethyl-3-phenylcyclopropene constitutes a class of mini-tag probes that participate in fast biorthogonal ligations reactions with 1,2,3,4-tetrazines and photoclickable tetrazoles [48].

Table 1. Compounds identified in C. maritimum hydromethanolic extract by GC-MS.

\begin{tabular}{cccl}
\hline Peak & $\mathbf{R}_{\mathbf{t}}$ (min) & Area (\%) & \multicolumn{1}{c}{ Tentative Assignments } \\
\hline 11 & 9.842 & 2.78 & $\begin{array}{l}\text { benzene, 2-methoxy-4-methyl-1-(1-methylethyl)- (also named methylthymol); } \\
\text { 3-methoxy-p-cymene (also named 2-isopropyl-5-methylanisole or tymol methyl ether) }\end{array}$ \\
\hline 15 & 11.005 & 0.88 & $\begin{array}{l}\text { 2-methoxy-4-vinylphenol (or 4-vinylguaiacol); } \\
\text { 1-(2-hydroxy-5-methylphenyl)ethanone; 3-methoxyacetophenone }\end{array}$ \\
\hline 21 & 14.068 & 0.80 & $\begin{array}{l}\text { 1,2,3-trimethoxy-5-allylbenzene (or elemicin) } \\
\text { 1-allyl-2,5-dimethoxy-3,4-methylenedioxybenzene (or apiole) }\end{array}$ \\
\hline 33 & 15.163 & 54.58 & $\begin{array}{l}\text { ethyl 2-(3-hydroxyphenyl)acetate } \\
\text { methanol, cyclohexylphenyl-1-(4-hydroxyphenyl)-2-(3-hydroxyphenyl)ethane }\end{array}$ \\
\hline 50 & 18.143 & 0.92 & $\begin{array}{l}\text { falcarinol; propenoic acid, 3-(cycloheptatrien-7-yl-, methyl ester } \\
\text { N,N-dimethyl-1H-inden-2-amine }\end{array}$ \\
\hline 51 & 19.170 & 3.78 & $\begin{array}{l}\text { 1-methyl-4-nitrosobenzene; bicyclo[4.2.0]octa-1,3,5-trien-7-ol } \\
\text { 1,2-dimethyl-3-phenylcyclopropene; } \alpha \text {-methyl-2-naphthalenemethanol dimethyl; } \\
\text { 1,2-diethenyl tricyclo[3.1.0.0(2,4)]hexane-3,6-dicarboxylate }\end{array}$ \\
\hline
\end{tabular}

Major constituents of the hydromethanolic extract of D. carota subsp. gummifer (Table 2, Figure S5) were: (Z)-3,7-dimethyl-2,6-octadien-1-ol, acetate (or geranyl acetate) $[\mathrm{m} / \mathrm{z}=$ $41,69,80,93,107,121,136$, and 154]), any of the three following: 1,2-dicyclohexyl-1,1propanedicarbonitrile; 1,6-dibromohexane or 3-methylbut-2-enoic acid, 3,5-dimethylphenyl ester; anhydro-4,6-dimethyl-3-[p-chlorophenyl]-7-hydroxy-1,2,4-triazolo[1,5-a]pyrimidinium5-one and/or bromocyclohexane; and $\gamma$-sitosterol. For comparison purposes, Gil Pinilla, et al. [7] reported the presence of geranyl acetate, linalool, sabinene, terpinen-4-ol, geraniol, $\alpha$ pinene, and $\beta$-pinene in the EO of D. carota subsp. gummifer from Santander, Cantabria, Spain. The main constituents of D. carota subsp. maritimus and D. carota "Nantes" EOs (from Turkey) reported by Majdoub, et al. [49] and Keser, et al. [50] were geranyl acetate, $\beta$-bisabolene, $\gamma$-bisabolene, terpinolene, elemicin, myristicin, 5-caffeoylquinic acid, 5 -feruoylquinic, and dicaffeic acid. In our study, instead of carotol sesquiterpene, reported by Valente, et al. [8], cariophyllene $[m / z=41,55,69,79,91,119,133,147,161,175$, and 189], cariophyllene oxide and farnesene sesquiterpenes were found. Caryophyllene oxide was also reported as a major compound of the hydrosol extract from aerial parts of Daucus carota subsp. sativus by Tabet Zatla, et al. [51]. Bisabolene was also registered, although as trans-Z- $\alpha$-bisabolene epoxide $\left(R_{t}=17.105\right)$ and in small amounts. For a thorough comparison of the main components of $D$. carota from different origins, the interested reader is referred to Bendiabdellah, et al. [52].

The possibility of exploitation of the two studied plants for agricultural chemicals industry applications is supported by above GC-MS results: apiole and dill-apiole, major constituents of $C$. maritimum, have been shown to be a good insecticide when they were isolated from the roots of Anethum graveolus L. [53], whereas geranyl acetate, the major component of $D$. carota, has antifungal and anti-inflammatory properties, referred in the studies by Gonçalves, et al. [54] and by Khayyat and Sameeh [55]. Thymol, a phytochemical from C. maritimun, interferes with the formation and viability of hyphae and induces morphological alterations in the envelope (i.e., the plasma membrane and the mannoproteins, enzymes, beta-glucans, and chitin of the wall) of C. albicans, and it also exhibits anti-inflammatory effects by reducing the production and gene expression of the pro-inflammatory mediators [56]. Falcarinol has also been identified as an important 
antifungal compound, inhibiting spore germination of various fungi in concentrations ranging from 20 to $200 \mu \mathrm{g} \cdot \mathrm{mL}^{-1}$ [57].

Table 2. Compounds identified in D. carota subsp. gummifer hydromethanolic extract by GC-MS.

\begin{tabular}{|c|c|c|c|}
\hline Peak & $R_{t}(\min )$ & Area $(\%)$ & Tentative Assignments \\
\hline 6 & 6.219 & 1.12 & $\begin{array}{l}\text { 1,6-anhydro-2,4-dideoxy- } \beta \text {-D-ribo-hexopyranose; propanoic acid, 2,2-dimethyl-, hexyl } \\
\text { ester; } 2 \text {-methylbutanal }\end{array}$ \\
\hline 20 & 11.925 & $22.73-39.68$ & (Z)-3,7-dimethyl-2,6-octadien-1-ol, acetate (or geranyl acetate) \\
\hline 22 & 12.519 & 2.70 & $\begin{array}{l}\text { caryophyllene; bicyclo[7.2.0]undec-4-ene, } \\
\left.\left.\text { 4,11,11-trimethyl-8-methylene-,[1R-(1R* } 4 \mathrm{Z}, 9 \mathrm{~S}^{*}\right)\right]\end{array}$ \\
\hline 26 & 13.254 & 1.87 & 2,6-dimethyl-3,5,7-octatriene-2-ol; geranyl acetate, 2,3-epoxy- \\
\hline 28 & 13.756 & 1.49 & (E,Z)- $\alpha$-farnesene; 6-epi-shyobunol; epiglobulol \\
\hline 34 & 14.569 & 1.30 & caryophyllene oxide; cyclohexaneethanol, 2-methylene- \\
\hline 40 & 15.528 & 1.35 & $\begin{array}{l}\text { 1,2,3,5-cyclohexanetetrol, }(1 \alpha, 2 \beta, 3 \alpha, 5 \beta) \text {-; 4-methyl-5-propyl-nonane; } \\
\text { trichloroacetic acid, } 4 \text {-methylpentyl ester }\end{array}$ \\
\hline 55 & 19.418 & 2.61 & $\begin{array}{l}\text { 4-hydroxy-4-(4,6-dimethylcyclohex-3-enyl)butan-2-one; } \\
\text { 3-buten-2-one, 4-(3-hydroxy-6,6-dimethyl-2-methylenecyclohexyl)-; } \\
\text { 7,8-epoxy- } \alpha \text {-ionone }\end{array}$ \\
\hline 59 & 19.920 & 0.65 & $\begin{array}{l}\text { spiro[4.5]decan-7-one, 1,8-dimethyl-8,9-epoxy-4-isopropyl-; } \\
\text { biciclo[4,1,0]heptan-3-ol,3,7,7-trimethyl-, [1S- } 1 \alpha, 3 \alpha, 6 \alpha]-\end{array}$ \\
\hline 62 & 20.163 & 1.23 & 3-carene; tricyclo[2.2.1.0(2,6)]heptane, 1,3,3-trimethyl- \\
\hline 63 & 20.431 & 1.16 & 5-ethyl-2,4-dimethyl-2-heptene; hexan-3-yl (E)-2-methylbut-2-enoate \\
\hline 84 & 23.201 & 1.33 & hexadecanoic acid, 2-hydroxy-1-(hydroxymethyl)ethyl ester \\
\hline 86 & 23.566 & 2.42 & $\begin{array}{l}\text { anhydro-4,6-dimethyl-3-[p-chlorophenyl]-7-hydroxy-1,2,4-triazolo[1,5- } \\
\text { a]pyrimidinium-5-one }\end{array}$ \\
\hline 91 & 24.593 & 2.38 & (9Z,12Z)-1,3-Dihydroxypropan-2-yl octadeca-9,12-dienoate (or $\beta$-monolinolein) \\
\hline 97 & 25.299 & 5.50 & $\begin{array}{l}\text { 1,2-dicyclohexyl-1,1-propanedicarbonitrile; 1,6-dibromohexane; } \\
\text { 3-methylbut-2-enoic acid, 3,5-dimethylphenyl ester }\end{array}$ \\
\hline 99 & 25.480 & 4.92 & 3-ethyl-2-butenoic acid, phenyl ester; bromocyclohexane \\
\hline 103 & 25.947 & 1.71 & 3-methyl-but-2-enoic acid, 1,7,7-trimethyl-bicyclo[2.2.1]hept-2-yl ester \\
\hline 107 & 30.192 & $2.52-6.95$ & $\gamma$-sitosterol \\
\hline
\end{tabular}

\subsection{In Vitro Antimicrobial Activity \\ 3.3.1. Antibacterial Activity}

The inhibition of both C. maritimum and D. carota extracts against Erwinia amylovora and Xylophilus ampelinus were similar (Table 3), although it was slightly higher against $X$. ampelinus in the case of $C$. maritimum. As regards the activities of the two main active principles, viz. pure apiole (an essential oil) and pure geranyl acetate (a monoterpene), the obtained results were comparable to or lower than those of the plant extracts. Another was the case for the conjugate complexes, in which a synergistic behavior was observed among $\mathrm{COS}$ and the phytochemicals in all cases. The best results against E. amylovora were attained with the COS-C. maritimum complex (MIC $=187.5 \mu \mathrm{g} \cdot \mathrm{mL}^{-1}$ ), while against $X$. ampelinus the lowest MIC $\left(125 \mu \mathrm{g} \cdot \mathrm{mL}^{-1}\right)$ corresponded to the COS-geranyl acetate complex, followed by the COS-C. maritimum complex (MIC $=250 \mu \mathrm{g} \cdot \mathrm{mL}^{-1}$ ).

The above results of antibacterial effect of chitosan-phytochemical conjugates against Erwinia spp. were in accordance with the previous reports [58,59], in which the chitosanphytochemical conjugates exhibited higher antimicrobial activity than that of unmodified chitosan. For instance, Kim, et al. [60] reported that the MICs of chitosan-phytochemical 
conjugates ranged from 32 to $512 \mu \mathrm{g} \cdot \mathrm{mL}^{-1}$ against foodborne pathogens, while the MICs of the unmodified chitosan were in the $128-1024 \mu \mathrm{g} \cdot \mathrm{mL}^{-1}$ range.

Table 3. Antibacterial activity of chitosan oligomers (COS), C. maritimum and D. carota subsp. gummifer extracts, pure apiole and geranyl acetate, and their corresponding conjugate complexes (COS-C. maritimum, COS-D. carota, COS-apiole and COS-geranyl acetate) against the two phytopathogenic bacteria under study at different concentrations (expressed in $\left.\mu \mathrm{g} \cdot \mathrm{mL}^{-1}\right)$.

\begin{tabular}{|c|c|c|c|c|c|c|c|c|c|c|c|}
\hline Pathogen & Compound & 62.5 & 93.7 & 125 & 187.5 & 250 & 375 & 500 & 750 & 1000 & 1500 \\
\hline \multirow{9}{*}{ E. amylovora } & COS & + & + & + & + & + & + & + & + & + & - \\
\hline & C. maritimum & + & + & + & + & + & + & + & + & + & - \\
\hline & D. carota & + & + & + & + & + & + & + & + & + & - \\
\hline & Apiole & + & + & + & + & + & + & + & + & + & - \\
\hline & Geranyl acetate & + & + & + & + & + & + & + & + & + & + \\
\hline & COS-apiole & + & + & + & + & + & + & + & - & - & - \\
\hline & COS-geranyl acetate & + & + & + & + & + & + & + & + & - & - \\
\hline & COS-C. maritimum & + & + & + & + & - & - & - & - & - & - \\
\hline & COS-D. carota & + & + & + & + & + & + & - & - & - & - \\
\hline \multirow{9}{*}{ X. ampelinus } & COS & + & + & + & + & + & + & + & + & + & - \\
\hline & C. maritimum & + & + & + & + & + & + & + & - & - & - \\
\hline & D. carota & + & + & + & + & + & + & + & + & - & - \\
\hline & Apiole & + & + & + & + & + & + & + & + & + & - \\
\hline & Geranyl acetate & + & + & + & + & + & + & + & + & + & - \\
\hline & COS-apiole & + & + & + & + & + & + & + & - & - & - \\
\hline & COS-geranyl acetate & + & + & + & - & - & - & - & - & - & - \\
\hline & COS-C. maritimum & + & + & + & + & + & - & - & - & - & - \\
\hline & COS-D. carota & + & + & + & + & + & + & - & - & - & - \\
\hline
\end{tabular}

"+" and "-" indicate presence and absence of bacterial growth, respectively.

In line with Kim, et al. [60], it may be speculated that the mechanism of action behind this enhanced behavior operates via multiple mechanisms: positively charged chitosan can interact with the negatively charged bacterial cell surface, which leads to a weakening of the cell wall, either by cell wall damage alone or accompanied by cell lysis. Conjugation with phytochemicals may increase the osmotic pressure-induced disruption and shrinkage of the bacterial membrane because of a reduction in the permeability of the membrane to intracellular components, and the conjugates may also form a barrier on the bacterial surface and prevent the entry of nutrients. It may also be hypothesized that conjugation with phytochemicals increases the affinity of chitosan for the bacterial cell envelope because of an enhanced lipophilicity (conferred-in the case of apiol-by the allyl side chain bonded to the aromatic ring; and, in the case of geranyl acetate, by the presence of two double bonds in the unsaturated chain). In any case, it should be taken into consideration that further research is required to support aforementioned hypotheses.

\subsubsection{Antifungal Activity}

Diplodia seriata mycelial growth inhibition results are presented in Figure 2 and Figrue S6. The preconized antifungal activity of D. carota [8], based on its relatively high content of terpenes, was not observed in our assays. That of $C$. maritimum was also low, with $\mathrm{EC}_{50}$ and $\mathrm{EC}_{90}$ values of 832 and $2933 \mu \mathrm{g} \cdot \mathrm{mL}^{-1}$, respectively. Even when its main component, apiole (whose antifungal effect has been referred to the presence of two methoxyl groups in positions 2, 3 of their benzene ring, optimum to gain a correct balance of hydrophilicitylipophilicity [61]), was assayed as a pure substance, the results were moderate, with $\mathrm{EC}_{50}$ and $\mathrm{EC}_{90}$ values of 333 and $822 \mu \mathrm{g} \cdot \mathrm{mL}^{-1}$, respectively.

These results are in line with the low activity of $D$. carota $\mathrm{EO}$ against certain Candida spp. and Aspergillus spp. reported by Valente, et al. [8], and with the lack of activity of apiole against C. acutatum, C. fragariae, C. gloeosporioides, and F. oxysporium reported by Meepagala, et al. [62]. 
Another was the case for geranyl acetate, the main component of $D$. carota: when it was assayed as a pure substance, it led to $\mathrm{EC}_{50}$ and $\mathrm{EC}_{90}$ values as low as 147 and $172 \mu \mathrm{g} \cdot \mathrm{mL}^{-1}$, respectively.

Regarding the activity of the conjugate complexes with COS, an enhancement in the antifungal activity was registered in all cases. The lowest $\mathrm{EC}_{50}$ and $\mathrm{EC}_{90}$ values were obtained for COS-geranyl acetate (68 and $113 \mu \mathrm{g} \cdot \mathrm{mL}^{-1}$, respectively) and for COS-C. maritimum extract ( 75 and $331 \mu \mathrm{g} \cdot \mathrm{mL}^{-1}$, respectively), for which a synergy factor above 5 was obtained (Table 4).

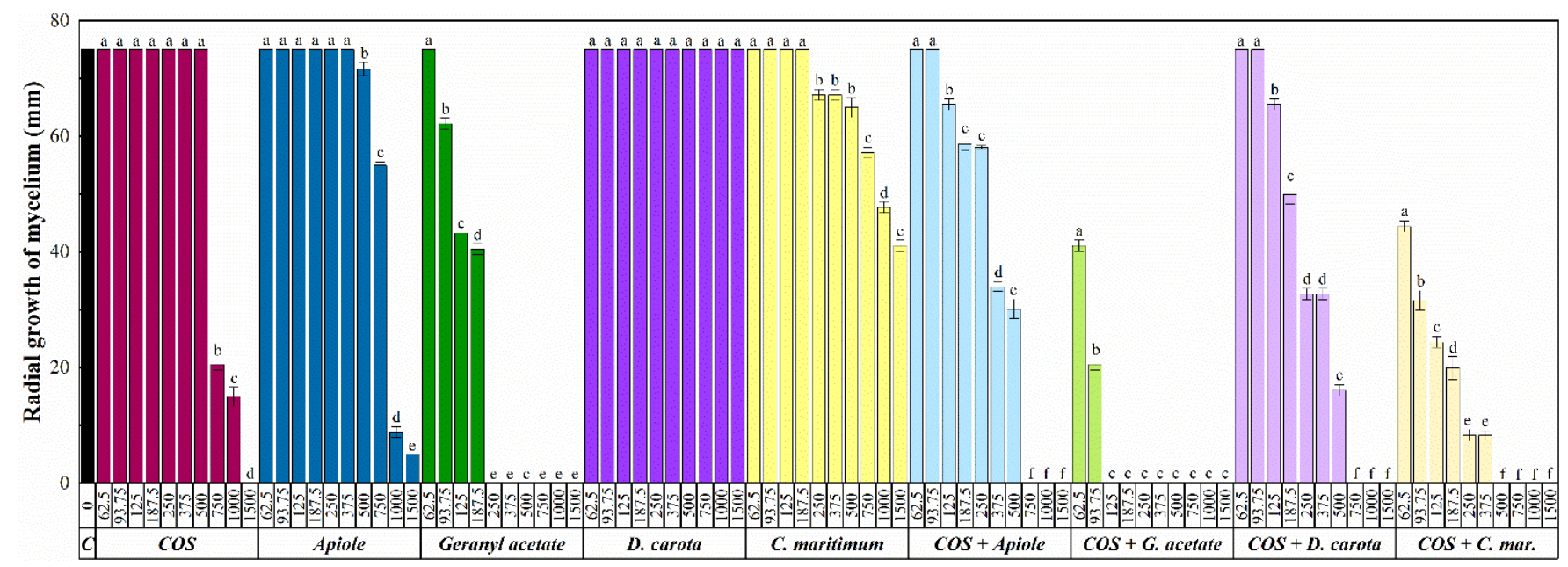

Figure 2. Radial growth of the mycelium for D. seriata in in vitro tests conducted in PDA medium with different concentrations $\left(62.5,93.75,125,187.5,250,375,500,750,1000\right.$, and $\left.1500 \mu \mathrm{g} \cdot \mathrm{mL}^{-1}\right)$ of chitosan oligomers (COS), C. maritimum extract and pure apiole, D. carota extract and pure geranyl acetate, and their respective conjugate complexes. The same letters above concentrations mean that they are not significantly different at $p<0.05$. Error bars represent standard deviations.

Table 4. $\mathrm{EC}_{50}$ and $\mathrm{EC}_{90}$ effective concentrations for the different treatments, expressed in $\mu \mathrm{g} \cdot \mathrm{mL}^{-1}$, and synergy factors estimated according to Wadley's method.

\begin{tabular}{cccccccccc}
\hline $\begin{array}{c}\text { Effective } \\
\text { Concentration }\end{array}$ & COS & Apiole & $\begin{array}{c}\text { Geranyl } \\
\text { Acetate }\end{array}$ & D. carota & $\begin{array}{c}C . \\
\text { maritimum }\end{array}$ & COS-Apiol & $\begin{array}{c}\text { COS-Geranyl } \\
\text { Acetate }\end{array}$ & $\begin{array}{c}\text { COS-D. } \\
\text { carota }\end{array}$ & $\begin{array}{c}\text { COS-C. } \\
\text { maritimum }\end{array}$ \\
\hline $\mathrm{EC}_{50}$ & 744 & 807 & 147 & - & 832 & 333 & 68 & 269 & 75 \\
$\mathrm{EC} 90$ & 1180 & 1353 & 272 & - & 2933 & 822 & 113 & 633 & 331 \\
\hline $\mathrm{SF}$ & & & & & & 1.53 & 3.91 & - & 5.08 \\
\hline
\end{tabular}

$\mathrm{SF}=$ synergy factor.

The molecular mechanisms behind chitosan interactions with fungi have been recently discussed in a review paper by Lopez-Moya, et al. [63]. Nonetheless, the information available on the mechanism of synergistic action of COS-phytochemical conjugates is not well-established yet. It has been hypothesized that it may be the result of an enhanced additive fungicidal effect per se, and/or via a concurrent action on diverse fungal metabolic sites. The conjugation with phytochemicals may increase the cationic surface charge of COS, enhancing the linkage (through electrostatic interactions) to the negatively charged site-specific binding receptors on the fungal membrane $[28,64-66]$.

\subsubsection{Comparison with Efficacies Reported in the Literature}

Results from studies on the antimicrobial activity of the specific bioactive substances under study (C. maritimum and D. carota extracts, apiol, and geranyl acetate) against diverse foodborne and clinical bacteria and fungi are summarized in Table 5. The reported MICs and $\mathrm{IC}_{50}$ values are generally lower than those reported herein (in this work, the lowest MIC values were 125 and $187.5 \mu \mathrm{g} \cdot \mathrm{mL}^{-1}$ against X. ampelinus and E. amylovora, respectively, and the lowest $\mathrm{EC}_{50}$ and $\mathrm{EC}_{90}$ values against $D$. seriata were 68 and $113 \mu \mathrm{g} \cdot \mathrm{mL}^{-1}$, respec- 
tively), but it is worth noting that there are certain pathogens for which no inhibition could be attained, and that there is a large variability in the reported values depending on the bioactive product (and its provenance) and even as a function of the strain/isolate for the same pathogen. A comparison with the values reported for other phytopathogens was not possible, given that no inhibition could be attained using a hexane extract of C. maritimum leaves against Erwinia carotovara subsp. carotovora, and the minimum inhibitory quantity $(\mathrm{MIQ}=1 \mu \mathrm{L} / \mathrm{disc})$ reported using $C$. maritimum roots essential oil against Mycogone perniciosa was not expressed in standard units.

A comparison can instead be made with the efficacy of other natural products reported in the literature against the actual phytopathogens under study. To the best of the authors' knowledge, no assays with plant-derived products have been conducted against $X$. ampelinus, but E. amylovora has the subject of several studies, summarized in Table 6. In this work, the lowest MIC value against E. amylovora was $187.5 \mu \mathrm{g} \cdot \mathrm{mL}^{-1}$, better than those attained with the extracts from Damask rose and golden wreath wattle flowers, Conocarpus lancifolius leaves and different phenolic extracts from clove, oregano, artichoke, or walnut shells. Nonetheless, lower MICs have been reported for the resinous exudates from Adesmia boronioides and alkaloids from African rue seeds.

Table 5. Antibacterial and antifungal activities of C. maritimum and D. carota extracts, apiol, and geranyl acetate reported in the literature.

\begin{tabular}{|c|c|c|c|c|}
\hline Phytochemical & Product Type & Microorganisms & Effectiveness & Ref \\
\hline \multirow[t]{2}{*}{ Apiole } & $\begin{array}{l}\text { EO from rhizomes of } \\
\text { Athamanta turbith } \\
\text { 33-49\% apiole }\end{array}$ & $\begin{array}{c}\text { Bacteria: } \\
\text { E. coli ATCC } 25922 \\
\text { P. aeruginosa ATCC } 27853 \\
\text { S. aureus ATCC } 25923 \\
\text { S. epidermidis ATCC } 12228 \\
\text { M. luteus ATCC } 10240 \\
\text { K. pneumoniae NCIMB } 9111 \\
\text { Fungi: } \\
\text { C. albicans ATCC } 10259\end{array}$ & $\begin{array}{c}\text { MIC }\left(\mathrm{mg} \cdot \mathrm{mL}^{-1}\right) \\
43.3 \\
>86.6 \\
43.3 \\
86.6 \\
43.3 \\
>86.6 \\
\\
>86.6\end{array}$ & [67] \\
\hline & $\begin{array}{c}\text { EO from aerial parts of } \\
\text { Piper holtonii } \\
57 \% \text { apiole }\end{array}$ & $\begin{array}{c}\text { Fungi: } \\
\text { Colletotrichum acutatum } \\
\text { Botryodiplodia theobromae }\end{array}$ & $\begin{array}{c}\mathrm{IC}_{50}\left(\mu \mathrm{g} \cdot \mathrm{mL}^{-1}\right) \\
<50 \\
36.16\end{array}$ & [61] \\
\hline \multirow[b]{2}{*}{ Geranyl acetate } & $\begin{array}{l}\text { EO of lemongrass } \\
\text { varieties } \\
0.5-1 \% \text { geranyl ac. }\end{array}$ & $\begin{array}{c}\text { Bacteria: } \\
\text { P. aeruginosa } \\
\text { S. aureus }\end{array}$ & $\begin{array}{c}\mathrm{MIC}\left(\mu \mathrm{g} \cdot \mathrm{mL}^{-1}\right) \\
4.5-9 \\
4.5-18\end{array}$ & [55] \\
\hline & $\begin{array}{l}\text { EO from aerial parts of } \\
\text { Thapsia minor: } \\
\text { 83\% geranyl acetate }\end{array}$ & $\begin{array}{c}\text { Fungi: } \\
\text { C. albicans ATCC } 10231 \\
\text { C. tropicalis ATCC } 13803 \\
\text { C. krusei H9 } \\
\text { C. guillermondii MAT23 } \\
\text { C. parapsilosis ATCC } 90018 \\
\text { T. rubrum CECT } 2794 \\
\text { M. gypseum CECT } 2905 \\
\text { M. canis FF1 } \\
\text { C. neoformans CECT1078 } \\
\text { E. floccosum FF9 } \\
\text { A. flavus F44 } \\
\text { A. niger ATCC16404 } \\
\text { A. fumigatus ATCC } 46645\end{array}$ & $\begin{array}{c}\mathrm{MIC}\left(\mu \mathrm{L} \cdot \mathrm{mL}^{-1}\right) \\
>20 \\
>20 \\
10-20 \\
1.25 \\
2.5-5 \\
0.32 \\
0.64 \\
0.32-0.64 \\
0.32 \\
0.16 \\
>20 \\
>20 \\
10-20\end{array}$ & [54] \\
\hline
\end{tabular}


Table 5. Cont

\begin{tabular}{|c|c|c|c|c|}
\hline Phytochemical & Product Type & Microorganisms & Effectiveness & Ref \\
\hline \multirow{19}{*}{$\begin{array}{l}\text { D. carota subsp. } \\
\text { gummifer }\end{array}$} & \multirow{13}{*}{$\begin{array}{l}\text { EO of aerial parts, } \\
37 \% \text { geranyl acetate }\end{array}$} & Fungi: & $\operatorname{MIC}\left(\mu \mathrm{L} \cdot \mathrm{mL}^{-1}\right)$ & \multirow{13}{*}{ [8] } \\
\hline & & C. albicans ATCC 10231 & $>20$ & \\
\hline & & C. tropicalis ATCC 13803 & 10 & \\
\hline & & C. krusei $\mathrm{H} 9$ & $>20$ & \\
\hline & & C. guillermondii MAT 23 & 1.25 & \\
\hline & & C. parapsilosis ATCC 90018 & $>20$ & \\
\hline & & T. rubrum CECT 2794 & 0.32 & \\
\hline & & M. gypseum CЕСТ 2908 & 0.64 & \\
\hline & & M. canis FF1 & 0.64 & \\
\hline & & E. floccosum FF9 & 0.32 & \\
\hline & & A. flavus F44 & $>20$ & \\
\hline & & A. niger ATCC 16404 & 10 & \\
\hline & & A. fumigatus ATCC 46645 & 2.5 & \\
\hline & \multirow{6}{*}{$\begin{array}{l}\text { EO of aerial parts } \\
52-77 \% \text { geranyl ac. }\end{array}$} & $\begin{array}{c}\text { Bacteria: } \\
\text { E. coli ATCC } 25922\end{array}$ & $\begin{array}{c}\mathrm{MIC}\left(\mathrm{mg} \cdot \mathrm{mL}^{-1}\right) \\
>6.0\end{array}$ & \multirow{6}{*}{ [15] } \\
\hline & & P. aeruginosa ATCC 27853 & $>6.0$ & \\
\hline & & S. aureus ATCC 25923 & 5.1 & \\
\hline & & B. cereus ATCC 9634 & 3.8 & \\
\hline & & E. faecalis ATCC 29212 & 4.3 & \\
\hline & & K. pneumoniae ATCC 10031 & $>6.0$ & \\
\hline \multirow{4}{*}{$\begin{array}{l}\text { D. carota subsp. } \\
\text { hispidus }\end{array}$} & \multirow{4}{*}{ EO of aerial parts } & Bacteria: & $\operatorname{MIC}\left(\mathrm{mg} \cdot \mathrm{mL}^{-1}\right)$ & \multirow{4}{*}[68]{} \\
\hline & & E. coli ATCC 35218 & 1.25 & \\
\hline & & S. aureus ATCC 25923 & 2.5 & \\
\hline & & E. faecalis ATCC 29212 & 1.25 & \\
\hline \multirow{24}{*}{ C. maritimum } & & Bacteria: & & \\
\hline & & E. coli ATCC 10536 & $\mathrm{IC}_{50}=0.47 \mathrm{mg} \cdot \mathrm{mL}^{-1}$ & \\
\hline & $\begin{array}{c}\text { Plant extract and EU of } \\
\text { aerial parts }\end{array}$ & P. aeruginosa ATCC 9027 & (Kélibia) and 3.3 & [30] \\
\hline & & S. aureus ATCC 6538 & $\mathrm{mg} \cdot \mathrm{mL}^{-1}$ (Monastir) & \\
\hline & & B. cereus ATCC 11778 & & \\
\hline & & Fungi: & $\operatorname{MIC}\left(\mu \mathrm{g} \cdot \mathrm{mL}^{-1}\right)$ & \\
\hline & Hyaromethanonc & E. coli ATCC 25922 & 0.11 & [10] \\
\hline & & C. albicans ATCC 10231 & 0.11 & \\
\hline & & Bacteria: & $\mathrm{MIC}\left(\mu \mathrm{g} \cdot \mathrm{mL}^{-1}\right)$ & \multirow{7}{*}{ [47] } \\
\hline & & E. coli BCC 3.08.001 and ATCC 4157 & - & \\
\hline & & B. cereus BCC 3.05 .002 & 50 & \\
\hline & Hexane extract of & M. luteus ATCC 10240 & 50 & \\
\hline & & E. carotovora BCC 3.08 .031 & - & \\
\hline & & Fungi: & & \\
\hline & & C. albicans BCC 3.08.036. & - & \\
\hline & \multirow{8}{*}{ Volatile oils of leaves } & Fungi: & $\operatorname{MIC}\left(\mu \mathrm{g} \cdot \mathrm{mL}^{-1}\right)$ & \multirow{8}{*}{ [69] } \\
\hline & & C. albicans ATCC 10231 & $2.5-5$ & \\
\hline & & C. guillermondii MAT23 & $0.32-2.5$ & \\
\hline & & C. neoformans CECT 1078 & $0.32-0.64$ & \\
\hline & & E. floccosum FF9 & $0.08-0.32$ & \\
\hline & & T. rubrum CECT 2794 & $0.08-0.32$ & \\
\hline & & M. gypseum CECT 2908 & $0.08-1.25$ & \\
\hline & & M. canis FF1 & $0.08-0.64$ & \\
\hline & Essential oil of roots & M. perniciosa & $\mathrm{MIQ}=1 \mu \mathrm{L} / \operatorname{disc}$ & [17] \\
\hline
\end{tabular}

In relation to the antifungal activity against $D$. seriata, the lowest $\mathrm{EC}_{50}$ and $\mathrm{EC}_{90}$ values for the products assayed herein were 68 and $113 \mu \mathrm{g} \cdot \mathrm{mL}^{-1}$, respectively. These were substantially lower than those attained with other natural compounds. For instance, a concentration of $1000 \mu \mathrm{g} \cdot \mathrm{mL}^{-1}$ was required to completely inhibit the mycelial growth of D. seriata for chitosan oligosaccharides (molecular weight < $3000 \mathrm{Da}$ ) [80]; and only 
$96.8 \%$ growth inhibition was reached for chitosan at $25 \mathrm{mg} \cdot \mathrm{mL}^{-1}$ [80]. Growth inhibition percentages of 20.6, 90.5, 47.7, 68.2, and 77.8\% were reported by Cobos, et al. [80] for Evernia prunastri lichen extract (4\%), garlic extract $(10 \%)$, lemon peel extract $(10 \%)$, propolis $\left(10 \mathrm{mg} \cdot \mathrm{mL}^{-1}\right)$, and vanillin $\left(5 \mathrm{mg} \cdot \mathrm{mL}^{-1}\right)$, respectively. If COS-conjugate complexes are considered instead, the $\mathrm{EC}_{90}$ values attained with a COS- $\varepsilon$-polylysine conjugate $\left(580 \mu \mathrm{g} \cdot \mathrm{mL}^{-1}\right)$ [28], and a COS-tyrosine conjugate $\left(672 \mu \mathrm{g} \cdot \mathrm{mL}^{-1}\right)$ [65] were substantially higher than those obtained for COS-geranyl acetate and COS-C. maritimum extract, and comparable to those of COS-apiol and COS-D. carota subsp. gummifer extract.

Table 6. Natural products assayed against Erwinia amylovora.

\begin{tabular}{|c|c|c|}
\hline Phytochemical & Effective Dose & Ref. \\
\hline EO of Rosa damascena flowers & $\mathrm{MCB}=1386.5 \mu \mathrm{g} \cdot \mathrm{mL}^{-1}$ & [70] \\
\hline Water extract $(7.4 \% w / w)$ of Acacia saligna flowers & $\mathrm{MIC}=300 \mu \mathrm{g} \cdot \mathrm{mL}^{-1}$ & [71] \\
\hline Alkaloids extract from Conocarpus lancifolius leaves & $\mathrm{MIC}>200 \mu \mathrm{g} \cdot \mathrm{mL}^{-1}$ & [72] \\
\hline Phenolic extracts from: & $\mathrm{MIC}\left(\mathrm{mg} \cdot \mathrm{mL}^{-1}\right)$ & \multirow{5}{*}[73]{} \\
\hline Syzygium aromaticum & 10.2 & \\
\hline Origanum vulgare & $91 \%$ inhibition at 41.0 & \\
\hline Cynara cardunculus var. scolymus stem & $48 \%$ inhibition at 41.0 & \\
\hline Juglans regia shells & No inhibition & \\
\hline $\begin{array}{l}\text { Exudate from Adesmia boronioides ( } 8.5 \% \text { resin/fresh } \\
\text { plant) }\end{array}$ & $\mathrm{MIC}=64 \mu \mathrm{g} \cdot \mathrm{mL}^{-1}$ & [74] \\
\hline Alkaloids extr. from Peganum harmala seeds & $\mathrm{MIC}=50 \mu \mathrm{g} \cdot \mathrm{mL}^{-1}$ & [75] \\
\hline Extracts from Coccoloba uvifera leaves: & $\begin{array}{l}\text { Diam. inhib. zone }(\mathrm{mm}) \text { at } \\
2500 \mu \mathrm{g} \cdot \mathrm{mL}^{-1}\end{array}$ & \multirow{4}{*}{ [76] } \\
\hline Aqueous & $8 \pm 1$ & \\
\hline Acetone & $10 \pm 1$ & \\
\hline Ethanol & 14 & \\
\hline EO from: & $\begin{array}{l}\text { Diam. inhib. zone (mm), } \\
\text { concentr. N/A }\end{array}$ & \multirow{9}{*}{ [77] } \\
\hline Cinnamomum zeylanicum & 31.2 & \\
\hline Laurus nobilis & 22 & \\
\hline Thymus vulgaris & 20.6 & \\
\hline Syzygium aromaticum & 18 & \\
\hline Pinus spp. & 17 & \\
\hline Cymbogon citratus & 13 & \\
\hline Mentha spicata & 13 & \\
\hline Melaleuca alternifolia & 12 & \\
\hline EO from aerial parts of flowering: & $\begin{array}{l}\text { Diam. inhib. zone (mm), } \\
\text { concentr. N/A }\end{array}$ & \multirow{3}{*}[78]{} \\
\hline Thymus vulgaris & 25 & \\
\hline Satureja hortensis & 25 & \\
\hline EOs extr. by steam or hydrodistillation from: & $\begin{array}{l}\text { Diam. inhib. zone }(\mathrm{cm}), \\
\text { concentr. N/A }\end{array}$ & \multirow{7}{*}{ [79] } \\
\hline Melissa officinalis flowers/leaves & $6.17-8.7$ & \\
\hline Mentha arvensis aerial part & $7.67-12.7$ & \\
\hline Nepeta cataria flowering tops & $12.1-24.00$ & \\
\hline Origanum compactum aerial part & $21.33-29.3$ & \\
\hline Origanum vulgare aerial part & $14.50-25.5$ & \\
\hline Thymus vulgaris aerial part & $14.33-37.0$ & \\
\hline
\end{tabular}

\section{Conclusions}

The hydromethanolic extract of the aerial parts of C. maritimum was found to be rich in apiole $(55 \%)$ and that of $D$. carota in geranyl acetate $(40 \%)$. In the in vitro assays, a strong 
synergistic behavior was observed upon conjugation of the bioactive constituents of plant extracts with chitosan oligosaccharides, with synergy factors in the 3.9-5.1 range. For the COS-C. maritimum complex, MIC values of 187.5 and $250 \mu \mathrm{g} \cdot \mathrm{mL}^{-1}$ were obtained against $E$. amylovora and X. ampelinus, respectively; and $\mathrm{EC}_{50}$ and $\mathrm{EC}_{90}$ values of 75 and $331 \mu \mathrm{g} \cdot \mathrm{mL}^{-1}$ were found against $D$. seriata. For COS-D. carota extract, a MIC value of $375 \mu \mathrm{g} \cdot \mathrm{mL}^{-1}$ was observed against the two bacterial phytopathogens; and an $\mathrm{EC}_{90}$ of $633 \mu \mathrm{g} \cdot \mathrm{mL}^{-1}$ was attained against $D$. seriata. Taking into consideration that the conjugate complexes of both halophyte extracts showed a better performance than other natural compounds reported in the literature against E. amylovora and D. seriata, they may be put forward as promising antimicrobial treatments, either in organic agriculture or as a substitute for treatments based on chemical synthesis fungicides in conventional management.

Supplementary Materials: The following are available online at https://www.mdpi.com/article/10 .3390/agronomy11050886/s1, Table S1: Elemental (CHNSO) composition (wt.\%) of C. maritimum and D. carota fractions; Table S2: Elemental composition (wt.\%) of C. maritimum and D. carota flowering aerial parts concentrate hydromethanolic extracts; Table S3: Main bands in the ATR-FTIR spectra of various C. maritimum and D. carota subsp. gummifer fractions and their assignments; Table S4: GC/MS analysis of C. maritimum hydromethanolic extract; Table S5: GC/MS analysis of D. carota subsp. gummifer hydromethanolic extract; Figure S1: TG, DSC and DTG curves for C. maritimum; Figure S2: TG, DSC and DTG curves for D. carota subsp. gummifer; Figure S3: ATR-FTIR spectrum of D. carota subsp. gummifer hydromethanolic extract; Figure S4: GC-MS spectrum of C. maritimum hydromethanolic extract; Figure S5: GC-MS spectrum of D. carota subsp. gummifer hydromethanolic extract; Figure S6: Sensitivity test for D. seriata.

Author Contributions: Conceptualization, J.M.-G., C.A.-J. and P.M.-R.; methodology, B.L.-V.; validation, C.A.-J., B.L.-V., J.M.-G. and P.M.-R.; formal analysis, P.M.-R.; investigation, E.S.-H., L.B.-D., C.A.-J., B.L.-V., J.M.-G. and P.M.-R.; resources, J.M.-G. and P.M.-R.; writing-original draft preparation, E.S.-H., L.B.-D., C.A.-J., B.L.-V., J.M.-G. and P.M.-R.; writing-review and editing, P.M.-R.; visualization, E.S.-H. and L.B.-D.; supervision, L.B.-D. and P.M.-R.; project administration, J.M.-G. and P.M.-R.; funding acquisition, J.M.-G. and P.M.-R. All authors have read and agreed to the published version of the manuscript.

Funding: This research was funded by Junta de Castilla y León under project VA258P18, with FEDER co-funding; by Cátedra Agrobank under "IV Convocatoria de Ayudas de la Cátedra AgroBank para la transferencia del conocimiento al sector agroalimentario" program; and by Fundación IbercajaUniversidad de Zaragoza under "Convocatoria Fundación Ibercaja-Universidad de Zaragoza de proyectos de investigación, desarrollo e innovación para jóvenes investigadores" program. Instituto Universitario de Investigación en Ciencias Ambientales de Aragón (IUCA) is gratefully acknowledged for covering the APCs.

Institutional Review Board Statement: Not applicable.

Informed Consent Statement: Not applicable.

Data Availability Statement: The data presented in this study are available on request from the corresponding author. The data are not publicly available due to their relevance to be part of an ongoing Ph.D. Thesis.

Acknowledgments: The authors gratefully acknowledge the support of Pilar Blasco and Pablo Candela at the Servicios Técnicos de Investigación, Universidad de Alicante, for conducting the GC-MS analyses.

Conflicts of Interest: The funders had no role in the design of the study; in the collection, analyses, or interpretation of data; in the writing of the manuscript, or in the decision to publish the results.

\section{References}

1. Atia, A.; Barhoumi, Z.; Mokded, R.; Abdelly, C.; Smaoui, A. Environmental eco-physiology and economical potential of the halophyte Crithmum maritimum L. (Apiaceae). J. Med. Plants Res. 2011, 5, 3564-3571.

2. Bolarinwa, I.F.; Oke, M.O.; Olaniyan, S.A.; Ajala, A.S. A review of cyanogenic glycosides in edible plants. In Toxicology-New Aspects to This Scientific Conundrum; Larramendy, M.L., Soloneski, S., Eds.; InTechOpen: Rijeka, Croatia, 2016; pp. 179-192. [CrossRef] 
3. Quattrocchi, U. CRC World Dictionary of Medicinal and Poisonous Plants: Common Names, Scientific Names, Eponyms, Synonyms, and Etymology; CRC: Boca Raton, FL, USA, 2012; p. 3960.

4. Males, Z.; Zuntar, I.; Nigovic, B.; Plazibat, M.; Vundac, V.B. Quantitative analysis of the polyphenols of the aerial parts of rock samphire -Crithmum maritimum L. Acta Pharm. 2003, 53, 139-144. [PubMed]

5. Bartnik, M.; Wierzchowska-Renke, K.; Głowniak, P.; Głowniak, K. Phenolic acids in underground parts of Crithmum maritimum L. In Proceedings of the Jubilee XXXth Symposium, Chromatographic Methods of Investigating the Organic Compounds, Katowice, Szczyrk, Poland, 12-14 June 2006; p. 108.

6. Pavela, R.; Maggi, F.; Lupidi, G.; Cianfaglione, K.; Dauvergne, X.; Bruno, M.; Benelli, G. Efficacy of sea fennel (Crithmum maritimum L., Apiaceae) essential oils against Culex quinquefasciatus Say and Spodoptera littoralis (Boisd.). Ind. Crop. Prod. 2017, 109, 603-610. [CrossRef]

7. Gil Pinilla, M.; Pérez-Alonso, M.J.; Velasco-Negueruela, A. Volatile constituents from fruits of Daucus carota L., subsp. Gummifer Hooker Fil. J. Essent. Oil Res. 1995, 7, 433-435. [CrossRef]

8. Valente, J.; Zuzarte, M.; Resende, R.; Goncalves, M.J.; Cavaleiro, C.; Pereira, C.F.; Cruz, M.T.; Salgueiro, L. Daucus carota subsp gummifer essential oil as a natural source of antifungal and anti-inflammatory drugs. Ind. Crop. Prod. 2015, 65, 361-366. [CrossRef]

9. Houta, O.; Akrout, A.; Najja, H.; Neffati, M.; Amri, H. Chemical composition, antioxidant and antimicrobial activities of essential oil from Crithmum maritimum cultivated in Tunisia. J. Essent. Oil Bear. Plants 2015, 18, 1459-1466. [CrossRef]

10. Nabet, N.; Boudries, H.; Chougui, N.; Loupassaki, S.; Souagui, S.; Burlo, F.; Hernandez, F.; Carbonell-Barrachina, A.A.; Madani, K.; Larbat, R. Biological activities and secondary compound composition from Crithmum maritimum aerial parts. Int. J. Food Prop. 2017, 20, 1843-1855. [CrossRef]

11. Meot-Duros, L.; Le Floch, G.; Magne, C. Radical scavenging, antioxidant and antimicrobial activities of halophytic species. J. Ethnopharmacol. 2008, 116, 258-262. [CrossRef]

12. Rossi, P.-G.; Berti, L.; Panighi, J.; Luciani, A.; Maury, J.; Muselli, A.; de Rocca Serra, D.; Gonny, M.; Bolla, J.-M. Antibacterial action of essential oils from Corsica. J. Essent. Oil Res. 2007, 19, 176-182. [CrossRef]

13. Ozcelik, B.; Kusmenoglu, S.; Turkoz, S.; Abbasoglu, U. Antimicrobial activities of plants from the Apicaceae. Pharm. Biol. 2004, 42, 526-528. [CrossRef]

14. Pavoni, L.; Maggi, F.; Mancianti, F.; Nardoni, S.; Ebani, V.V.; Cespi, M.; Bonacucina, G.; Palmieri, G.F. Microemulsions: An effective encapsulation tool to enhance the antimicrobial activity of selected EOs. J. Drug Deliv. Sci. Technol. 2019, 53. [CrossRef]

15. Nawel, M.; El Amine, D.B.; Hocine, A.; Boufeldja, T. Comparative analysis of essential oil components of two Daucus species from Algeria and their antimicrobial activity. Int. Res. J. Biol. Sci. 2013, 2, 22-29.

16. Ruberto, G.; Baratta, M.T.; Deans, S.G.; Dorman, H.J.D. Antioxidant and antimicrobial activity of Foeniculum vulgare and Crithmum maritimum essential oils. Planta Med. 2000, 66, 687-693. [CrossRef] [PubMed]

17. Glamoclija, J.; Sokovic, M.; Grubisic, D.; Vukojevic, J.; Milinekovic, I.; Ristic, M. Antifungal activity of Crithmum maritimum essential oil and its components against mushroom pathogen Mycogone perniciosa. Chem. Nat. Compd. 2009, 45, 96-97. [CrossRef]

18. Donat, V.; Biosca, E.G.; Peñalver, J.; López, M.M. Exploring diversity among Spanish strains of Erwinia amylovora and possible infection sources. J. Appl. Microbiol. 2007, 103, 1639-1649. [CrossRef] [PubMed]

19. Piqué, N.; Miñana-Galbis, D.; Merino, S.; Tomás, J. Virulence factors of Erwinia amylovora: A review. Int. J. Mol. Sci. 2015, 16, 12836-12854. [CrossRef]

20. Zhao, Y.-Q.; Tian, Y.-L.; Wang, L.-M.; Geng, G.-M.; Zhao, W.-J.; Hu, B.-S.; Zhao, Y.-F. Fire blight disease, a fast-approaching threat to apple and pear production in China. J. Integr. Agric. 2019, 18, 815-820. [CrossRef]

21. Willems, A.; Gillis, M.; Kersters, K.; Van Den Broecke, L.; De Ley, J. Transfer of Xanthomonas ampelina Panagopoulos 1969 to a new genus, Xylophilus gen. nov., as Xylophilus ampelinus (Panagopoulos 1969) comb. nov. Int. J. Syst. Bacteriol. 1987, 37, 422-430. [CrossRef]

22. Szegedi, E.; Civerolo, E.L. Bacterial diseases of grapevine. Int. J. Hortic. Sci. 2011, 17. [CrossRef]

23. Larignon, P.; Fulchic, R.; Cere, L.; Dubos, B. Observation on black dead arm in French vineyards. Phytopathol. Mediterr. 2001, 40, 336-342.

24. Mondello, V.; Songy, A.; Battiston, E.; Pinto, C.; Coppin, C.; Trotel-Aziz, P.; Clement, C.; Mugnai, L.; Fontaine, F. Grapevine trunk diseases: A review of fifteen years of trials for their control with chemicals and biocontrol agents. Plant Dis. 2018, 102, 1189-1217. [CrossRef] [PubMed]

25. Stevens, N.E. Two apple black rot fungi in the United States. Mycologia 2018, 25, 536-548. [CrossRef]

26. Brown-Rytlewski, D.E.; McManus, P.S. Virulence of Botryosphaeria dothidea and Botryosphaeria obtusa on apple and management of stem cankers with fungicides. Plant Dis. 2000, 84, 1031-1037. [CrossRef] [PubMed]

27. Brown, E.A. Botryosphaeria diseases of apple and peach in the Southeastern Unites States. Plant Dis. 1986, 70. [CrossRef]

28. Buzón-Durán, L.; Martín-Gil, J.; Pérez-Lebeña, E.; Ruano-Rosa, D.; Revuelta, J.L.; Casanova-Gascón, J.; Ramos-Sánchez, M.C.; Martín-Ramos, P. Antifungal agents based on chitosan oligomers, $\varepsilon$-polylysine and Streptomyces spp. secondary metabolites against three Botryosphaeriaceae species. Antibiotics 2019, 8, 99. [CrossRef] [PubMed]

29. Martin, M.T.; Cobos, R. Identification of fungi associated with grapevine decline in Castilla y León (Spain). Phytopathol. Mediterr. 2007, 46, 18-25. 
30. Jallali, I.; Zaouali, Y.; Missaoui, I.; Smeoui, A.; Abdelly, C.; Ksouri, R. Variability of antioxidant and antibacterial effects of essential oils and acetonic extracts of two edible halophytes: Crithmum maritimum L. and Inula crithmoides L. Food Chem. 2014, 145, 1031-1038. [CrossRef]

31. Garcia Camacho, F.; Grima, E.M.; Martínez Sancho, M.; Sánchez Villasclaras, S. Determinación de ácidos grasos en microalgas marinas. Comparación de diversos métodos de extracción de la fracción lipídica. Grasas Aceites 1990, 41, 13-18.

32. CLSI. Methods for Dilution Antimicrobial Susceptibility Tests for Bacteria that Grow Aerobically, 11th ed.; CLSI Standard M07; Clinical and Laboratory Standards Institute: Wayne, PA, USA, 2018.

33. Arendrup, M.C.; Cuenca-Estrella, M.; Lass-Flörl, C.; Hope, W. EUCAST technical note on the EUCAST definitive document EDef 7.2: Method for the determination of broth dilution minimum inhibitory concentrations of antifungal agents for yeasts EDef 7.2 (EUCAST-AFST). Clin. Microbiol. Infect. 2012, 18, E246-E247. [CrossRef] [PubMed]

34. Wadley, F.M. The Evidence Required to Show Synergistic Action of Insecticides and a Short Cut in Analysis; U.S. Government Printing Office: Washington, DC, USA, 1945.

35. Ramiah, M.V. Thermogravimetric and differential thermal analysis of cellulose, hemicellulose, and lignin. J. Appl. Polym. Sci. 1970, 14, 1323-1337. [CrossRef]

36. Sotiroudis, V.T.; Sotiroudis, T.G.; Kolisis, F.N. The potential of biodiesel production from fatty acid methyl esters of some European/Mediterranean and cosmopolitan halophyte seed oils. J. ASTM Int. 2010, 7. [CrossRef]

37. Sene, C.F.B.; McCann, M.C.; Wilson, R.H.; Grinter, R. Fourier-transform Raman and Fourier-transform infrared spectroscopy (an investigation of five higher plant cell walls and their components). Plant Physiol. 1994, 106, 1623-1631. [CrossRef]

38. Abideen, Z.; Ansari, R.; Khan, M.A. Halophytes: Potential source of ligno-cellulosic biomass for ethanol production. Biomass Bioenergy 2011, 35, 1818-1822. [CrossRef]

39. Guil-Guerrero, J.L.; Rodríguez-García, I. Lipids classes, fatty acids and carotenes of the leaves of six edible wild plants. Eur. Food Res. Technol. 1999, 209, 313-316. [CrossRef]

40. Najjaa, H.; Abdelkarim, B.A.; Doria, E.; Boubakri, A.; Trabelsi, N.; Falleh, H.; Tlili, H.; Neffati, M. Phenolic composition of some Tunisian medicinal plants associated with anti-proliferative effect on human breast cancer MCF-7 cells. Eurobiotech J. 2020, 4, 104-112. [CrossRef]

41. Ksouri, A.; Dob, T.; Belkebir, A.; Krimat, S.; Chelghoum, C. Chemical composition and antioxidant activity of the essential oil and the methanol extract of Algerian wild carrot Daucus carota L. ssp. carota (L.) Thell. J. Mater. Environ. Sci. 2015, 6, 784-791.

42. Raju, M.; Varakumar, S.; Lakshminarayana, R.; Krishnakantha, T.; Baskaran, V. Carotenoid composition and vitamin A activity of medicinally important green leafy vegetables. Food Chem. 2007, 101, 1598-1605. [CrossRef]

43. Ngom, S.; Breant, L.; Antheaume, C.; Herrmann, S.; Leick, A.; Muller, J.; Mekideche, N.; Lobstein, A. Anti-inflammatory compounds from Crithmum maritimum. Planta Med. 2009, 75, 940. [CrossRef]

44. Ben Mustapha, M.; Zardi-Bergaoui, A.; Chaieb, I.; Flamini, G.; Ascrizzi, R.; Ben Jannet, H. Chemical composition and insecticidal activity of Crithmum maritimum L. essential oil against stored-product beetle Tribolium castaneum. Chem. Biodivers. 2020, 17. [CrossRef] [PubMed]

45. Alves-Silva, J.M.; Guerra, I.; Goncalves, M.J.; Cavaleiro, C.; Cruz, M.T.; Figueirinha, A.; Salgueiro, L. Chemical composition of Crithmum maritimum L. essential oil and hydrodistillation residual water by GC-MS and HPLC-DAD-MS/MS, and their biological activities. Ind. Crop. Prod. 2020, 149. [CrossRef]

46. Ozcan, M.M.; Pedro, L.G.; Figueiredo, A.C.; Barroso, J.G. Constituents of the essential oil of sea fennel (Crithmum maritimum L.) growing wild in Turkey. J. Med. Food 2006, 9, 128-130. [CrossRef]

47. Meot-Duros, L.; Cerantola, S.; Talarmin, H.; Le Meur, C.; Le Floch, G.; Magne, C. New antibacterial and cytotoxic activities of falcarindiol isolated in Crithmum maritimum L. leaf extract. Food Chem. Toxicol. 2010, 48, 553-557. [CrossRef]

48. Ravasco, J.M.J.M.; Monteiro, C.M.; Trindade, A.F. Cyclopropenes: A new tool for the study of biological systems. Org. Chem. Front. 2017, 4, 1167-1198. [CrossRef]

49. Majdoub, S.; El Mokni, R.; Muradalievich, A.A.; Piras, A.; Porcedda, S.; Hammami, S. Effect of pressure variation on the efficiency of supercritical fluid extraction of wild carrot (Daucus carota subsp. maritimus) extracts. J. Chromatogr. B 2019, 1125. [CrossRef]

50. Keser, D.; Guclu, G.; Kelebek, H.; Keskin, M.; Soysal, Y.; Sekerli, Y.E.; Arslan, A.; Selli, S. Characterization of aroma and phenolic composition of carrot (Daucus carota 'Nantes') powders obtained from intermittent microwave drying using GC-MS and LC-MS/MS. Food Bioprod. Process. 2020, 119, 350-359. [CrossRef]

51. Tabet Zatla, A.; Dib, M.E.A.; Djabou, N.; Ilias, F.; Costa, J.; Muselli, A. Antifungal activities of essential oils and hydrosol extracts of Daucus carota subsp. sativus for the control of fungal pathogens, in particular gray rot of strawberry during storage. J. Essent. Oil Res. 2017, 29, 391-399. [CrossRef]

52. Bendiabdellah, A.; Dib, M.E.A.; Djabou, N.; Hassani, F.; Paolini, J.; Tabti, B.; Costa, J.; Muselli, A. Daucus carota ssp. hispanicus Gouan. essential oils: Chemical variability and fungitoxic activity. J. Essent. Oil Res. 2014, 26, 427-440. [CrossRef]

53. Lichtenstein, E.P.; Liang, T.T.; Schulz, K.R.; Schnoes, H.K.; Carter, G.T. Insecticidal and synergistic components isolated from dill plants. J. Agric. Food Chem. 1974, 22, 658-664. [CrossRef]

54. Gonçalves, M.J.; Cruz, M.T.; Tavares, A.C.; Cavaleiro, C.; Lopes, M.C.; Canhoto, J.; Salgueiro, L. Composition and biological activity of the essential oil from Thapsia minor, a new source of geranyl acetate. Ind. Crop. Prod. 2012, 35, 166-171. [CrossRef]

55. Khayyat, S.A.; Sameeh, M.Y. Bioactive epoxides and hydroperoxides derived from naturally monoterpene geranyl acetate. Saudi Pharm. J. 2018, 26, 14-19. [CrossRef] 
56. Braga, P.C.; Alfieri, M.; Culici, M.; Dal Sasso, M. Inhibitory activity of thymol against the formation and viability of Candida albicans hyphae. Mycoses 2007, 50, 502-506. [CrossRef]

57. Christensen, L.P. Bioactivity of polyacetylenes in food plants. In Bioactive Foods in Promoting Health; Watson, R.R., Preedy, V.R., Eds.; Elsevier: Amsterdam, The Netherlands, 2010; pp. 285-306. [CrossRef]

58. Lee, D.-S.; Woo, J.-Y.; Ahn, C.-B.; Je, J.-Y. Chitosan-hydroxycinnamic acid conjugates: Preparation, antioxidant and antimicrobial activity. Food Chem. 2014, 148, 97-104. [CrossRef]

59. Kim, Y.-M.; Jung, W.-K.; Je, J.-Y.; Kim, K.-H.; Kim, H.-W.; Lee, J.; Myeong, J.-I.; Lee, D.-S.; Kang, S.-K.; Eom, S.-H. Synergistic antibacterial effect and antibacterial action mode of chitosan-ferulic acid conjugate against methicillin-resistant Staphylococcus aureus. J. Microbiol. Biotechnol. 2016, 26, 784-789. [CrossRef]

60. Kim, J.-H.; Yu, D.; Eom, S.-H.; Kim, S.-H.; Oh, J.; Jung, W.K.; Kim, Y.-M. Synergistic antibacterial effects of chitosan-caffeic acid conjugate against antibiotic-resistant acne-related bacteria. Mar. Drugs 2017, 15, 167. [CrossRef]

61. Pineda, M.R.; Vizcaíno, P.S.; García, P.C.M.; Gil, G.J.H.; Durango, R.D.L. Chemical composition and antifungal activity of Piper auritum Kunth and Piper holtonii C. DC. against phytopathogenic fungi. Chil. J. Agric. Res. 2012, 72, 507-515. [CrossRef]

62. Meepagala, K.M.; Sturtz, G.; Wedge, D.E.; Schrader, K.K.; Duke, S.O. Phytotoxic and antifungal compounds from two Apiaceae species, Lomatium californicum and Ligusticum hultenii, rich sources of Z-ligustilide and apiol, respectively. J. Chem. Ecol. 2005, 31, 1567-1578. [CrossRef]

63. Lopez-Moya, F.; Suarez-Fernandez, M.; Vicente Lopez-Llorca, L. Molecular mechanisms of chitosan interactions with fungi and plants. Int. J. Mol. Sci. 2019, 20, 332. [CrossRef]

64. Liang, C.; Yuan, F.; Liu, F.; Wang, Y.; Gao, Y. Structure and antimicrobial mechanism of $\varepsilon$-polylysine-chitosan conjugates through Maillard reaction. Int. J. Biol. Macromol. 2014, 70, 427-434. [CrossRef]

65. Buzón-Durán, L.; Langa-Lomba, N.; González-García, V.; Casanova-Gascón, J.; Martín-Gil, J.; Pérez-Lebeña, E.; Martín-Ramos, P. On the applicability of chitosan oligomers-amino acid conjugate complexes as eco-friendly fungicides against grapevine trunk pathogens. Agronomy 2021, 11, 324. [CrossRef]

66. Buzón-Durán, L.; Martín-Gil, J.; Marcos-Robles, J.L.; Fombellida-Villafruela, Á.; Pérez-Lebeña, E.; Martín-Ramos, P. Antifungal Activity of Chitosan Oligomers-Amino Acid Conjugate Complexes against Fusarium culmorum in Spelt (Triticum spelta L.). Agronomy 2020, 10, 1427. [CrossRef]

67. Tomić, A.; Petrović, S.; Pavlović, M.; Tzakou, O.; Couladis, M.; Milenković, M.; Vučićević, D.; Lakušić, B. Composition and antimicrobial activity of the rhizome essential oils of two Athamanta turbith subspecies. J. Essent. Oil Res. 2009, 21, 276-279. [CrossRef]

68. Snene, A.; Mokni, R.E.; Mahdhi, A.; Joshi, R.K.; Hammami, S. Comparative study of essential oils composition and in vitro antibacterial effects of two subspecies of Daucus carota growing in Tunisia. S. Afr. J. Bot. 2020, 130, 366-370. [CrossRef]

69. Marongiu, B.; Maxia, A.; Piras, A.; Porcedda, S.; Tuveri, E.; Gonçalves, M.J.; Cavaleiro, C.; Salgueiro, L. Isolation of Crithmum maritimum L. volatile oil by supercritical carbon dioxide extraction and biological assays. Nat. Prod. Res. 2007, 21, 1145-1150. [CrossRef]

70. Basım, E.; Basım, H. Note: Evaluation of antibacterial activity of essential oil of Rosa damascena on Erwinia amylovora. Phytoparasitica 2004, 32, 409-412. [CrossRef]

71. Al-Huqail, A.; Behiry, S.; Salem, M.; Ali, H.; Siddiqui, M.; Salem, A. Antifungal, antibacterial, and antioxidant activities of Acacia Saligna (Labill.) H. L. Wendl. flower extract: HPLC analysis of phenolic and flavonoid compounds. Molecules 2019, $24,700$. [CrossRef] [PubMed]

72. Ali, H.M.; Salem, M.Z.; Abdel-Megeed, A. In-vitro antibacterial activities of alkaloids extract from leaves of Conocarpus lancifolius Engl. J. Pure Appl. Microbiol. 2013, 7, 1903-1907.

73. Alkan, D.; Yemenicioğlu, A. Potential application of natural phenolic antimicrobials and edible film technology against bacterial plant pathogens. Food Hydrocoll. 2016, 55, 1-10. [CrossRef]

74. Montenegro, I.; Valenzuela, M.; Zamorano, N.; Santander, R.; Baez, C.; Madrid, A. Activity of Adesmia boronioides resinous exudate against phytopathogenic bacteria. Nat. Prod. Res. 2019,1-4. [CrossRef] [PubMed]

75. Shaheen, H.A.; Issa, M.Y. In vitro and in vivo activity of Peganum harmala L. alkaloids against phytopathogenic bacteria. Sci. Hortic. 2020, 264. [CrossRef]

76. Ashmawy, N.A.; Salem, M.Z.; El Shanhorey, N.; Al-Huqail, A.; Ali, H.M.; Behiry, S.I. Eco-friendly wood-biofungicidal and antibacterial activities of various Coccoloba uvifera L. leaf extracts: HPLC analysis of phenolic and flavonoid compounds. BioResources 2020, 15, 4165-4187.

77. Vanneste, J.L.; Boyd, R.J. Inhibition of Erwinia amylovora and potential antagonistic bacteria by essential oils and natural compounds. Acta Hortic. 2002, 590, 315-317. [CrossRef]

78. Karami, O.R.; Khodaverdi, M.; Ali, A.F. Antibacterial effect of effective compounds of Satureja hortensis and Thymus vulgaris essential oils against Erwinia amylovora. J. Agric. Sci. Technol. 2010, 12, 35-45.

79. Kokoskova, B.; Pavela, R.; Pouvova, D. Effectiveness of plant essential oils against Erwinia amylovora, Pseudomonas syringae pv. syringae and associated saprophytic bacteria on/in host plants. J. Plant Pathol. 2011, 93, 133-139.

80. Cobos, R.; Mateos, R.M.; Alvarez-Perez, J.M.; Olego, M.A.; Sevillano, S.; Gonzalez-Garcia, S.; Garzon-Jimeno, E.; Coque, J.J. Effectiveness of natural antifungal compounds in controlling infection by grapevine trunk disease pathogens through pruning wounds. Appl. Environ. Microbiol. 2015, 81. [CrossRef] [PubMed] 